Jurnal Pendidikan dan Pembelajaran Kimia, Vol. 8, No. 2, Tahun 2019.

Program Studi Kimia. FKIP. Universitas Lampung

https://jurnal.fkip.unila.ac.id/

\title{
Efektivitas Model Pembelajaran POGIL untuk Meningkatkan Kemampuan Pemecahan Masalah pada Materi Garam Menghidrolisis
}

\author{
Aqmarani Adzani Fitriana*, Ila Rosilawati, Chansyanah Diawati \\ FKIP Universitas Lampung, Jl. Prof. Dr. Soemantri Brojonegoro No.1 Bandarlampung \\ *email: raniadzani@gmail.com,Tel :+6289622528135
}

Received: July 22, 2019

Accepted: July 24, 2019

Online Published:July 26, 2019

\begin{abstract}
The Effectiveness of POGIL Learning Model to Increase Problem Solving Ability in Hydrolyzing Salt. This research was aimed to describe the effectiveness of the Process Oriented Guided Inquiry Learning (POGIL) learning model to increase problem solving ability in hydrolizing salt topic. The method of this research was quasi experimental with pretest-posttest control grup design. The population of this research were all students of XI MIA one of Senior High School in Lampung Selatan. The samples were taken using purposive sampling technique and obtained XI MIA 1 as experiment class and XI MIA 4 as control class. The t test were used as data analysis. The result showed that the average n-gain of problem solving ability applied by POGIL learning model was higher than the average n-gain of problem solving ability with conventional model. The concluded in this research was the POGIL learning model was effective to increase problem solving ability in hydolyzing salt topic.
\end{abstract}

Keywords : hydrolyzing salt, problem solving ability, POGIL model.

\begin{abstract}
Abstrak : Efektivitas Model Pembelajaran POGIL untuk Meningkatkan Kemampuan Pemecahan Masalah pada Materi Garam Menghidrolisis. Penelitian ini bertujuan untuk mendeskripsikan efektivitas model pembelajaran Process Oriented Guided Inquiry Learning (POGIL) untuk meningkatkan kemampuan pemecahan masalah pada materi garam menghidrolisis. Metode penelitian yang digunakan adalah kuasi eksperimen dengan pretest-posttest control grup design. Populasi penelitian ini adalah seluruh siswa kelas XI MIA salah satu SMA di Lampung Selatan. Sampel penelitian diambil menggunakan teknik purposive sampling dan diperoleh kelas XI MIA 1 sebagai kelas eksperimen dan kelas XI MIA 4 sebagai kelas kontrol. Analisis data menggunakan uji-t. Hasil penelitian menunjukkan bahwa rata-rata n-gain kemampuan pemecahan masalah yang diterapkan model pembelajaran POGIL lebih tinggi daripada rata - rata $n$-gain kemampuan pemecahan masalah dengan model pembelajaran konvensional. Berdasarkan hasil penelitian dapat disimpulkan bahwa model pembelajaran POGIL efektif untuk meningkatkan kemampuan pemecahan masalah pada materi garam menghidrolisis.
\end{abstract}

Kata Kunci: garam menghidrolisis, kemampuan pemecahan masalah, model POGIL. 


\section{PENDAHULUAN}

Di abad 21 atau yang sering disebut era globalisasi saat ini, terjadi perubahan yang sangat cepat dan sulit diprediksi dalam segala aspek kehidupan, khususnya dalam bidang ekonomi. Indonesia merupakan satu dari lima negara pendiri ASEAN atau Association of South East Asia Nations yang didirikan untuk menyepakati kerjasama dalam bidang ekonomi. Salah satu kesepakatan yang menjadi cikal bakal visi pembentukan ASEAN yaitu Masyarakat Ekonomi ASEAN (MEA). Dengan adanya MEA akan terjadi perdagangan barang, jasa, modal dan investasi yang bergerak bebas tanpa halangan secara geografis. Pertumbuhan ekonomi di kawasan ini diharapkan merata dan menjelma menjadi pasar dunia (Fathoni, 2015).

Keberadaan MEA di Indonesia memberikan dampak positif maupun negatif. Adapun dampak negatif dari MEA, yaitu tenaga kerja asing dengan mudah masuk dan bekerja di Indonesia sehingga persaingan tenaga kerja menjadi semakin ketat. Para tenaga kerja dari negara MEA memiliki kompetensi kerja yang lebih tinggi, tentunya akan memiliki kesempatan lebih luas untuk mendapatkan keuntungan ekonomi di dalam MEA. Hal inilah yang menjadi permasalahan dunia ketenagakerjaan di Indonesia sebagai suatu bangsa yang sedang berkembang dengan kualitas SDM yang rendah (Bagus, 2015).

\begin{tabular}{llr}
\multicolumn{1}{c}{ Dampak } & tersebut & dapat \\
dihadapi & dengan & cara \\
mempersiapkan & sumber & daya \\
manusia unggul yang menguasai & math \\
keterampilan hard skill serta & soft
\end{tabular}

skill. Salah satu soft skill yaitu kemampuan dalam memecahkan suatu masalah (Cottrell, 2005).

Kemampuan pemecahan masalah merupakan satu aspek yang sangat penting dalam kehidupan. Kemampuan pemecahan masalah dapat diterapkan dalam pembelajaran sehingga dapat menciptakan generasi yang berdaya analitis tinggi sehingga mampu menempatkan diri dalam bermacam-macam situasi (Behrman, Kliegman, dan Arvin, 2000).

Pembelajaran yang melatih kemampuan pemecahan masalah harus membuat siswa aktif mencari, mengolah, mengkonstruksi, untuk memperoleh pemahaman baru yang akan digunakan untuk memecahkan suatu masalah. Inquiry merupakan proses pembelajaran dimana siswa mengeksplorasi seluruh sumber daya yang ada untuk memperoleh pemahaman (Brickman, 2009). Peningkatan kemampuan pemecahan masalah dapat dilakukan dengan menerapkan pembelajaran inkuiri, sebab pembelajaran inkuiri memberikan kesempatan kepada peserta didik untuk mengkonstruksi sendiri pengetahuan mereka, sehingga peserta didik dapat mengembangkan pengetahuannya.

Salah satu model pembelajaran yang menggunakan pendekatan inkuiri dan dapat meningkatkan kemampuan pemecahan masalah siswa adalah model POGIL (Process Oriented Guided Inquiry Learning). Pembelajaran POGIL didasarkan pada prinsip-prinsip konstruktivis yang menekankan pada keaktifan siswa untuk belajar melalui interaksi kelompok dalam memecahkan masalah (Nugraheni, 2014).

Menurut Hale dan Mullen (2009), salah satu tujuan dari rancangan pengajaran POGIL yaitu 
untuk mengembangkan keterampilan proses orientasi seperti pemecahan masalah, berpikir kritis dan analitis, dan komunikasi lisan dan tulisan. Kegiatan model POGIL dibangun di atas kerangka siklus pembelajaran (learning cycle), sebuah pendekatan yang terbukti efektif dalam pembelajaran IPA (Simonson dan Shadle, 2013).

Pembelajaran POGIL menekankan penemuan pengetahuan baru dalam proses belajar peserta didik yang dilakukan secara kelompok maupun individu. Pada pelaksanaannya, siswa dihadapkan pada pertanyaan yang dapat digunakan untuk meningkatkan kemampuan memecahkan masalah, menyelesaikan masalah, melaporkan, metakognisi, dan tanggung jawab individu. Dalam model ini dilakukan pembagian tugas pada masingmasing anggota kelompok, sehingga setiap anggota kelompok berperan aktif dalam kegiatan pembelajaran. Langkah-langkah pembelajaran model POGIL meliputi: orientation, exploration, concept formation, application, dan closure, yaitu guru memberikan penguatan dan membimbing peserta didik untuk melakukan refleksi dan evaluasi kinerja kelompoknya (Hanson, 2006).

Beberapa penelitian yang mengkaji model pembelajaran POGIL dan pemecahan masalah, yaitu Septianawati (2017) mengkaji peningkatkan kemampuan pemecahan masalah matematis dan habits of mind siswa melalui model pembelajaran Process Oriented Guided Inquiry Learning (POGIL) hasilnya peningkatan kemampuan pemecahan masalah menggunakan model pembelajaran POGIL lebih tinggi daripada menggunakan pembelajaran konvensional. Selain itu, hasil penelitian Sanggaran, Doyan dan Verawati (2019) menyatakan bahwa pembelajaran POGIL dalam virtual laboratory dapat meningkatkan kemampuan pemecahan masalah siswa

Kenyataannya berdasarkan hasil wawancara dengan guru kimia satu SMA Bandarlampung diperoleh informasi bahwa pembelajaran kimia masih menggunakan pembelajaran konvensional, guru masih menjadi sumber pengetahuan utama siswa atau pembelajaran masih terpusat pada guru, sehingga siswa menjadi kurang aktif bertanya, cenderung hanya mendengarkan guru dan siswa kurang dilatihkan dalam mengaitkan konsep-konsep yang telah dipelajarinya untuk menyelesaikan masalah baru yang dihadapinya.

Salah satu kompetensi dasar (KD) dalam kurikulum 2013 yang harus dikuasai oleh siswa pada mata pelajaran kimia kelas XI IPA semester genap adalah KD 3.12 Menganalisis garam-garam yang mengalami hidrolisis. KD 4.12 Merancang, melakukan, dan menyimpulkan serta menyajikan hasil percobaan untuk menentukan jenis garam yang mengalami hidrolisis. Pada tahap orientasi, siswa diberikan wacana tentang berbagai macam garam dalam kehidupan sehari-hari dimana garamgaram tersebut memiliki $\mathrm{pH}$ yang berbeda-beda, kemudian di tahap eksplorasi siswa melakukan praktikum untuk menguji $\mathrm{pH}$ dan sifat larutan garam yang sering digunakan dalam kehidupan seharihari dan yang tersedia di laboratorium, lalu pada tahap penemuan konsep guru membimbing siswa dalam membangun konsep melalui pertanyaan-pertanyaan 
sampai siswa dapat mengetahui sifat larutan garam berdasarkan asam basa pembentuknya sehingga siswa dapat mengaplikasikan konsep yang telah ditemukan untuk menyelesaikan soal latihan yang diberikan guru pada tahap aplikasi dan pada tahap penutup guru memberikan penguatan dan siswa dapat mengomunikasikan dan menyimpulkan konsep yang didapat. Berdasarkan uraian tersebut, dalam artikel ini akan dipaparkan mengenai efektivitas model pembelajaran POGIL untuk meningkatkan kemampuan pemecahan masalah pada materi garam menghidrolisis.

\section{METODE}

Populasi dalam penelitian ini adalah semua siswa kelas XI MIA salah satu SMA di Lampung Selatan yang berjumlah 288 siswa dan terdiri dari 8 kelas. sampel dalam penelitian ini adalah dua kelas dari delapan kelas tersebut. Penelitian ini dilakukan pada dua kelas dengan kemampuan kognitif yang hampir sama, sehingga dipilih teknik pengambilan sampel yaitu teknik purposive sampling. Sampel dalam penelitian ini, yakni siswa kelas XI MIA 1 sebagai kelas eksperimen yang menggunakan model POGIL dan kelas XI MIA 4 sebagai kelas kontrol yang menggunakan pembelajaran konvensional.

Metode penelitian yang digunakan dalam penelitian ini adalah kuasi eksperimen dan desain penelitian menggunakan pretestposttest control grup design. Variabel bebas dalam penelitian adalah model pembelajaran. Model pembelajaran yang diterapkan yaitu model pembelajaran POGIL dan pembelajaran konvensional.
Variabel terikat adalah kemampuan pemecahan masalah siswa pada materi garam menghidrolisis. Variabel kontrol adalah materi garam menghidrolisis dan guru.

Instrumen yang digunakan dalam penelitian ini adalah RPP, LKS, soal pretes dan postes kemampuan pemecahan masalah. Instrumen yang digunakan dilakukan validitas isi menggunakan cara judgement oleh dosen pembimbing. Data yang diperoleh dalam penelitian ini berupa data utama yaitu data pretes dan postes kemampuan pemecahan masalah dan data pendukung yaitu data aktivitas siswa dan kinerja guru. Sebelum dilaksanakan pembelajaran, diadakan pretes di kedua kelas penelitian. Data skor pretes yang diperoleh diubah menjadi nilai dengan menggunakan rumus berikut:

Nilai pretes $=\frac{\sum \text { skor jawaban yang diperoleh }}{\sum \text { skor maksimal }} \times 100$

Kemudian dihitung rata-rata nilai pretes dengan menggunakan rumus :

Rata-rata nilai pretes $=\frac{\text { Jumlah nilai pretes }}{\text { Jumlah siswa }}$

\section{Uji Kesamaan Dua Rata-Rata}

Sebelum dilakukan uji
kesamaan dua rata-rata untuk
mengetahui apakah kemampuan
pemecahan masalah awal siswa di
kelas eksperimen sama secara
signifikan dengan kemampuan
pemecahan masalah awal siswa di
kelas kontrol, terlebih dahulu
dilakukan pengujian normalitas dan
homogenitas menggunakan SPSS
versi 23.0 sebagai uji prasyarat.
Dengan kriteria uji normalitas terima
$\mathrm{H}_{0}$ jika nilai sig dari


Kolmogorov-Smirnov $>0,05$, dan tolak $\mathrm{H}_{0}$ untuk harga lainnya. Kriteria uji homogenitas yaitu Terima $\mathrm{H}_{0}$ jika sig dari Levene statistics test $>0,05$, dan tolak $\mathrm{H}_{0}$ untuk harga lainnya.

Sampel dalam penelitian berasal dari populasi yang berdistribusi normal dan memiliki varians yang homogen, maka dilakukanlah uji parametrik dengan independent sample $T$ test. $\mathrm{Uji}$ ini dilakukan dengan kriteria pengujian terima $\mathrm{H}_{0}$ jika probabilitas $>0,05$ dan $\mathrm{H}_{1}$ jika probabilitas $<0,05$. Dengan hipotesis $\mathrm{H}_{0}=$ Rata-rata nilai pretes kemampuan pemecahan masalah siswa kelas eksperimen yang menggunakan model POGIL sama dengan rata-rata pretes kelas kontrol yang menggunakan pembelajaran konvensional dan $\mathrm{H}_{1}=$ Rata-rata nilai pretes kemampuan pemecahan masalah siswa kelas eksperimen yang menggunakan model POGIL tidak sama dengan rata-rata pretes kelas kontrol yang menggunakan pembelajaran konvensional.

\section{Uji Perbedaan Dua Rata-Rata}

Sampel diberikan perlakuan yang berbeda, kelas eksperimen diterapkan pembelajaran dengan model POGIL dan kelas kontrol diterapkan model pembelajaran konvensional. Setelah itu dilakukan postes pada kedua kelas penelitian. Nilai pretes dan postes digunakan untuk menghitung n-gain kemampuan pemecahan masalah dengan rumus berikut :

$n$-gain $=\frac{\% \text { nilai postes }-\% \text { nilai pretes }}{100-\% \text { nilai pretes }}$

Kemudian dihitung rata-rata $n$-gain dengan rumus : rata-rata $n$-gain $=\frac{\text { Jumlah n-gain seluruh siswa }}{\text { jumlah seluruh siswa }}$

Rata-rata n-gain yang diperoleh diinterpretasikan berdasarkan kriteria pengklasifikasian n-gain menurut Hake (1998), seperti pada Tabel 1.

Tabel 1. Klasifikasi n-gain

\begin{tabular}{cc}
\hline Besarnya $<\mathrm{g}>$ & Interpretasi \\
\hline$<\mathrm{g}>\geq 0,7$ & Tinggi \\
\hline $0,3 \leq<\mathrm{g}><0,7$ & Sedang \\
\hline$<\mathrm{g}><0,3$ & Rendah \\
\hline
\end{tabular}

Sebelum dilakukan uji perbedaan dua rata-rata untuk mengetahui keefektifan perlakuan terhadap sampel, dilakukan dengan melihat rata-rata n-gain kemampuan pemecahan masalah yang berbeda secara signifikan antara kelas eksperimen yang diterapkan model POGIL dan kelas kontro dengan model konvensional. Dilakukan terlebih dahulu uji normalitas dan homogenitas dan hasilnya normal dan homogen.

Uji perbedaan dua rata-rata ini menggunakan uji parametrik yang dilakukan menggunakan program SPSS versi 23 dengan independent sample $T$ test. Uji ini dilakukan dengan kriteria pengujian terima $\mathrm{H}_{0}$ jika probabilitas $>0,05$ dan $\mathrm{H}_{1}$ jika probabilitas $<0,05 . \mathrm{H}_{0}$ : Rata-rata $n$ gain kemampuan pemecahan masalah yang diterapkan pembelajaran POGIL lebih rendah atau sama dengan rata-rata n-gain kemampuan pemecahan masalah

siswa dengan pembelajaran konvensional dan $\mathrm{H}_{1}$ : Rata - rata n-gain kemampuan pemecahan 
masalah siswa yang diterapkan pembelajaran POGIL lebih tinggi daripada rata-rata n-gain kemampuan pemecahan masalah siswa dengan pembelajaran konvensional.

\section{HASIL DAN PEMBAHASAN}

Hasil penelitian diperoleh rata-rata nilai pretes kemampuan pemecahan masalah siswa pada kelas eksperimen dan kontrol yang disajikan pada Gambar 1.

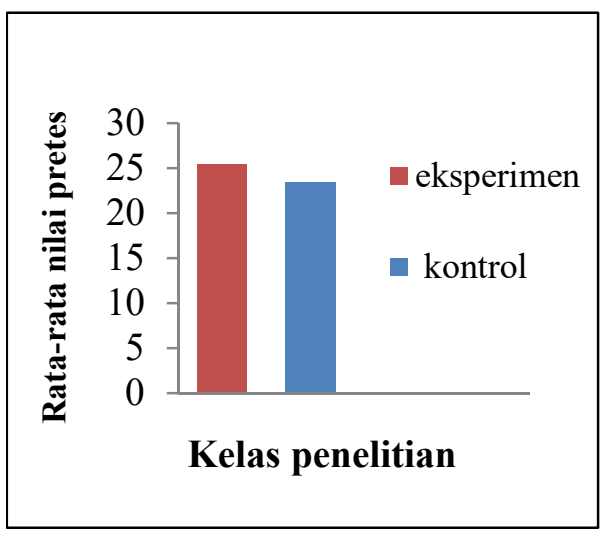

Gambar 1. Nilai rata-rata pretes kemampuan pemecahan masalah siswa

Pada Gambar diperoleh informasi bahwa nilai rata-rata pretes kemampuan pemecahan masalah siswa pada kelas eksperimen sebesar 25,34 dan rata-rata pretes di kelas kontrol sebesar 23,43 kemampuan pemecahan masalah siswa yang diperoleh kelas eksperimen dan kelas kontrol memiliki nilai yang relatif sama. Untuk menguji signifikasi kemampuan pemecahan masalah siswa pada kelas eksperimen relatif sama dengan kelas kontrol, maka dilakukan uji kesamaan dua ratarata. Sebelumnya dilakukan uji prasyarat yaitu uji normalitas dan uji homogenitas.
Uji normalitas pada penelitian ini menggunakan program SPSS versi 23 dengan uji one sample Kolmogrov-Smirnov test dengan kriteria uji terima $\mathrm{H}_{0}$ apabila hasil asymp sig. (2 tailed) $\geq 0,05$. Hasil uji normalitas terhadap nilai pretes kemampuan pemecahan masalah siswa disajikan pada Tabel 2.

Tabel 2. Hasil analisis statistik uji normalitas nilai pretes kemampuan pemecahan masalah siswa

\begin{tabular}{ccl} 
Kelas & $\begin{array}{c}\text { Asymp. Sig. 2- } \\
\text { tailed }\end{array}$ & Keterangan \\
\hline Eksperimen & $\begin{array}{c}0,087 \\
(\mathrm{p}>0,05)\end{array}$ & $\begin{array}{l}\text { berdistribusi } \\
\text { normal }\end{array}$ \\
\hline Kontrol & $\begin{array}{c}0,064 \\
(\mathrm{p}>0,05)\end{array}$ & $\begin{array}{l}\text { berdistribusi } \\
\text { normal }\end{array}$ \\
\hline
\end{tabular}

Berdasarkan hasil pada Tabel 2 uji normalitas yang telah dilakukan terhadap nilai pretes kemampuan pemecahan masalah siswa di kelas eksperimen $0,087>0,05$ dan di kelas kontrol $0,064>0,05$ hasil asymp sig. (2 tailed) $>0,05$, maka dapat disimpulkan terima $\mathrm{H}_{0}$ artinya kedua kelas penelitian berasal dari populasi yang berdistribusi normal. Setelah mengetahui kedua kelas berdistribusi normal, maka langkah selanjutnya adalah melakukan uji homogenitas. Uji homogenitas digunakan untuk mengetahui kedua kelas memiliki varians yang homogen atau tidak.

Berdasarkan hasil perhitungan uji homogenitas terhadap nilai pretes didapatkan hasil sig kemampuan pemecahan masalah siswa sebesar $0,478>0,05$, sehingga disimpulkan bahwa data sampel terima $\mathrm{H}_{0}$ artinya, data 
berasal dari kedua kelas penelitian memiliki varians yang homogen.

Sampel berasal dari populasi berdistribusi normal serta data yang diperoleh dari kedua kelas penelitian mempunyai variansi yang homogen, maka dilakukan uji kesamaan dua rata-rata nilai pretes kemampuan pemecahan masalah siswa. Uji ini menggunakan uji parametrik yang dilakukan menggunakan program SPSS versi 23 dengan independent sample $T$ test. Dengan kriteria pengujian terima $\mathrm{H}_{0}$ jika signifikan taraf kesalahan $\alpha=0,05$. Hasil sig. (2-tailed) uji kesamaan dua rata-rata terhadap nilai pretes yaitu $0,513>$ 0,05 terima $\mathrm{H}_{0}$. Artinya nilai ratarata pretes kemampuan pemecahan masalah siswa di kelas eksperimen dengan nilai rata-rata pretes siswa di kelas kontrol tersebut sama secara signifikan.

Setelah didapat nilai pretes dan postes dari kedua kelas penelitian, kemudian dilakukan perhitungan untuk mendapatkan n-gain. Setelah diperoleh n-gain, Berdasarkan Gambar 2 diperoleh informasi bahwa rata-rata n-gain kemampuan pemecahan masalah siswa di kelas eksperimen yaitu 0,710 berkriteria tinggi dan di kelas kontrol yaitu 0,469 berkriteria sedang. Kemampuan pemecahan masalah di kelas eksperimen yang diberi perlakuan model pembelajaran POGIL lebih tinggi dibandingkan dengan kelas kontrol yang menggunakan pembelajaran konvensional yang hanya melakukan langkah-langkah prosedur sesuai yang telah disediakan. Rata - rata n-gain kelas kontrol dan kelas eksperimen ditunjukkan pada Gambar 2.

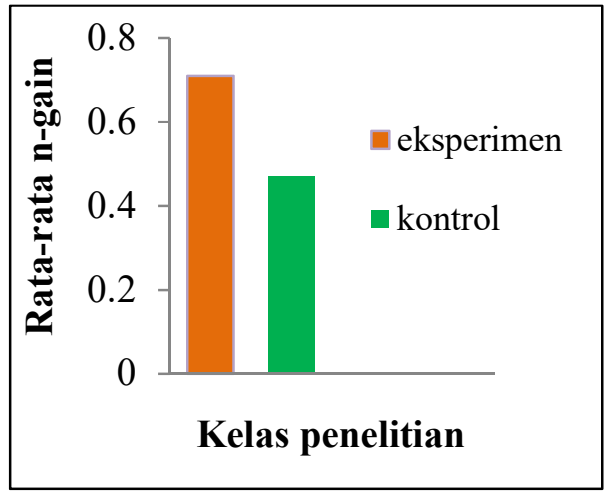

Gambar 2. Rata - rata $n$ - gain kemampuan pemecahan masalah

\begin{tabular}{lcc}
\multicolumn{2}{c}{ Pengujian } & efektivitas \\
kemampuan pemecahan & masalah, \\
dilakukan dengan uji & hipotesis \\
perbedaan dua & rata-rata.
\end{tabular}
Sebelumnya dilakukan uji prasyarat yaitu uji normalitas dan uji homogenitas terhadap n-gain. Uji normalitas pada n-gain kemampuan pemecahan masalah dilakukan dengan menggunakan program SPSS versi 23 dengan uji one sample Kolmogrov-Smirnov test dengan signifikan taraf kesalahan 0,05. Hasil uji normalitas n-gain dapat dilihat pada Tabel 3.

Tabel 3. Hasil analisis statistik uji normalitas n-gain kemampuan pemecahan masalah

\begin{tabular}{ccl} 
Kelas & $\begin{array}{c}\text { Asymp. Sig. 2- } \\
\text { tailed }\end{array}$ & Keterangan \\
\hline Eksperimen & $\begin{array}{c}0,200 \\
(\mathrm{p}>0,05)\end{array}$ & $\begin{array}{l}\text { berdistribusi } \\
\text { normal }\end{array}$ \\
\hline Kontrol & $\begin{array}{c}0,190 \\
(\mathrm{p}>0,05)\end{array}$ & $\begin{array}{l}\text { berdistribusi } \\
\text { normal }\end{array}$ \\
\hline \multicolumn{4}{c}{$\begin{array}{c}\text { Berdasarkan } \\
\text { diperoleh informasi }\end{array}$} & $\begin{array}{l}\text { Tabel bahwa } \\
\text { uji }\end{array}$
\end{tabular}


normalitas yang telah dilakukan terhadap n-gain kemampuan pemecahan masalah siswa pada kelas kontrol dan kelas eksperimen diperoleh hasil sig. $>0,05$. Artinya dapat disimpulkan bahwa terima $\mathrm{H}_{0}$ yang artinya kedua kelas penelitian berasal dari populasi yang berdistribusi normal. Setelah mengetahui kedua kelas berdistribusi normal, maka langkah selanjutnya adalah melakukan uji homogenitas $n$-gain kemampuan pemecahan masalah.

Uji homogenitas digunakan untuk mengetahui kedua kelas memiliki varians yang homogen atau tidak, menggunakan program SPSS versi 23 dengan test of homogeneity of variances. Pengujian terima $H_{0}$ pada taraf kesalahan $\sigma=0,05$. Berdasarkan hasil perhitungan uji homogenitas n-gain kemampuan pemecahan masalah siswa, didapatkan hasil sig. n-gain kemampuan pemecahan masalah $0,121>0,05$, sehingga disimpulkan bahwa data sampel terima $\mathrm{H}_{0}$, yaitu data yang berasal dari kedua kelas penelitian memiliki varians yang homogen.

Sampel berasal dari populasi berdistribusi normal serta data yang diperoleh dari kedua kelas penelitian mempunyai variansi yang homogen, maka dilakukan uji perbedaan dua rata-rata n-gain kemampuan pemecahan masalah. Uji ini menggunakan uji parametrik yang dilakukan menggunakan program SPSS versi 23 dengan independent sample $T$ test. Dengan kriteria pengujian terima $\mathrm{H}_{0}$ jika signifikan taraf kesalahan $\alpha=0,05$. Berdasarkan hasil perhitungan uji perbedaan dua rata-rata terhadap $n$-gain, didapatkan hasil sig 0,000<
0,05, sehingga terima $\mathrm{H}_{1}$, artinya rata-rata n-gain kemampuan pemecahan masalah siswa yang diterapkan model pembelajaran dengan menggunakan POGIL lebih tinggi daripada rata-rata n-gain kemampuan pemecahan masalah siswa dengan pembelajaran konvensional. Kesimpulannya model pembelajaran POGIL efektif untuk meningkatkan kemampuan pemecahan masalah siswa secara signifikan. Hal ini dapat dijelaskan dengan pengkajian sesuai dengan fakta yang terjadi pada kelas eksperimen. Proses pembelajaran yang menggunakan LKS POGIL pada materi garam menghidrolisis di kelas eksperimen meliputi 5 tahap yaitu, orientasi, eksplorasi, penemuan konsep, aplikasi dan penutup sehingga dapat dilatihkan kemampuan pemecahan masalah dalam tahapan tersebut.

\section{Tahap Orientasi}

Pada tahap ini siswa mengamati wacana yang diberikan guru yang tertuang dalam LKS dan pelaksanaannya siswa dibimbing untuk membaca sekaligus memahami wacana yang diberikan dan guru membimbing siswa dalam membangkitkan rasa ingin tahu dan sesekali guru mengaitkan pengetahuan sekarang dengan pengetahuan / pelajaran sebelumnya. Kemampuan pemecahan masalah siswa pada tahap ini ada pada saat memahami masalah siswa dapat menyebutkan informasi-informasi yang diberikan dan bertanya terkait dari wacana yang diberikan. Pada pembelajaran LKS 1, siswa mengamati wacana tentang berbagai 
macam garam dalam kehidupan sehari-hari seperti garam $\mathrm{NaCl}$, garam $\mathrm{NH}_{4} \mathrm{Cl}$ di dalam obat batuk, garam $\mathrm{CH}_{3} \mathrm{COONa}$ dan $\mathrm{CH}_{3} \mathrm{COONH}_{4}$ dimana keempat garam tersebut memiliki $\mathrm{pH}$ yang berbeda-beda. Saat siswa membaca dan mengamati wacana guru membimbing siswa untuk membangkitkan rasa ingin tahu siswa dengan bertanya "apakah ada yang ingin ditanyakan dari wacana tersebut".

Dari 6 kelompok, ada 3 kelompok yang mengajukan pertanyaan seperti, "mengapa garam itu rasanya asin bu?", "mengapa diobat batuk tidak asin?", "mengapa pHnya berbeda-beda?". Pada pembelajaran LKS 1 ini terlihat siswa masih pasif dalam bertanya dan pertanyaan yang diajukan belum sesuai dengan yang diharapkan guru.

Pada pembelajaran LKS 2 ditahap orientasi, wacana masih berhubungan dengan LKS 1 sehingga pertanyaan masih berkaitan dengan LKS 1. Pada pembelajaran LKS 3, siswa mengamati wacana berupa tabel hasil pengamatan $\mathrm{pH}$ beberapa larutan garam dan berdasarkan wacana tersebut siswa mengajukan pertanyaan "bagaimana cara mengidentifikasi sifat dari garamgaram yang bersifat netral, asam dan basa tanpa harus mengetahui $\mathrm{pH}$ nya?", "bagaimana mengetahui $\mathrm{pH}$ garam dengan rumus? ". Dari proses pembelajaran LKS 1 sampai 3 ditahap orientasi, aktivitas siswa dalam mengamati wacana semakin baik dan pada pembelajaran LKS 3 semua siswa sudah mampu bertanya sesuai dengan pertanyaan yang diharapkan guru.

\section{Tahap 2 Eksplorasi}

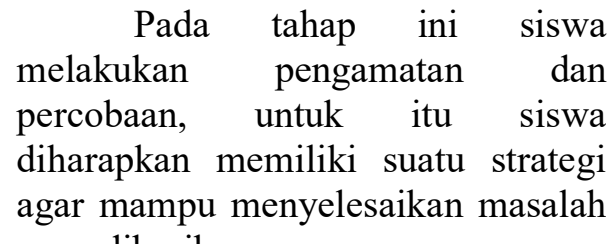
yang diberikan.

Pada pembelajaran LKS 1 siswa membaca wacana yang diberikan untuk merancang percobaan identifikasi larutan garam, dan sebelum siswa melakukan percobaan tersebut terlebih dahulu mengidentifikasi variabel-variabel untuk merancang percobaan. Jawaban siswa variabel kontrol "Molaritas atau konsentrasi dan Volume", Variabel bebas "nama larutan", variabel terikat "sifat larutan dan menentukan $\mathrm{pH}$ ". Penentuan variabel bebas masih belum tepat dikarenakan siswa hanya menuliskan "nama larutan". Seharusnya pada variabel bebas siswa menuliskan berbagai nama larutan garam yang terdapat dalam wacana tersebut yaitu larutan garam $\mathrm{NaCl}, \quad \mathrm{KCl}, \quad \mathrm{NH}_{4} \mathrm{Cl}, \quad\left(\mathrm{NH}_{4}\right)_{2} \mathrm{SO}_{4}$, $\mathrm{Na}_{2} \mathrm{CO}_{3}, \quad \mathrm{CH}_{3} \mathrm{COONa}$ dan $\mathrm{CH}_{3} \mathrm{COONH}_{4}$. Selanjutnya ketika sudah mengetahui variabel bebas, kontrol dan terikat barulah siswa membuat prosedur percobaan dan menentukan alat bahan yang digunakan untuk percobaan identifikasi larutan garam.

Prosedur percobaan yang dituliskan kelompok 3 sudah sesuai dengan jawaban yang diharapkan guru namun untuk alat yang digunakan tidak benar menggunakan plat tetes. Jika di prosedur kelompok 3 menuliskan menggunakan indikator universal sebaiknya untuk alat yang digunakan tidak 
menggunakan plat tetes lagi melainkan tabung reaksi. siswa membuat tabel hasil pengamatan untuk percobaan identifikasi larutan garam. hasil pengamatan yang dibuat oleh kelompok 3 masih kurang tepat. Begitu juga dengan kelompokkelompok lainnya ketika mempresentasikan rancangan dan tabel hasil pengamatan.

Kemudian guru membimbing siswa untuk merancang serta memberikan tabel yang sesuai untuk percobaan. Hasil rancangan yang telah disepakati kemudian digunakan untuk melakukan percobaan.

Pada pembelajaran LKS 2, siswa mengamati tabel data hasil percobaan penentuan $\mathrm{pH}$ air dan $\mathrm{pH}$ larutan garam $\mathrm{NaCl}, \mathrm{NH}_{4} \mathrm{Cl}$, $\mathrm{CH}_{3} \mathrm{COONa}$ dan larutan $\mathrm{NH}_{4} \mathrm{CN}$ dengan volume masing-masing larutan yang sama yaitu $5 \mathrm{ml}$.

Pada LKS 3 tahap eksplorasi terbagi menjadi 3 penggalan. Penggalan pertama siswa mengamati persamaan reaksi garam menghidrolisis $\mathrm{NH}_{4} \mathrm{Cl}$. Penggalan kedua mengamati persamaan reaksi garam menghidrolisis $\mathrm{CH}_{3} \mathrm{COONa}$ dan penggalan ketiga mengamati persamaan reaksi garam menghidrolisis $\mathrm{CH}_{3} \mathrm{COONH}_{4}$.

Dalam kegiatan pembelajaran pada LKS 1 siswa masih banyak bertanya dan kebingungan dalam diskusi kelompok, karena beberapa siswa saja yang aktif dalam pembelajaran. Saat pembelajaran LKS 2 dan 3 siswa mengamati tabel percobaan dan reaksi garam menghidrolisis dengan fokus sehingga pertanyaan yang ditanyakan siswa sudah sesuai dengan pertanyaan yang diharapkan guru.

\section{Tahap Penemuan konsep}

Pada tahap ini, guru memberikan pertanyaan-pertanyaan yang tertuang dalam LKS, guru memberikan waktu untuk menjawab pertanyaanpertanyaan tersebut, jika ada siswa yang kesulitan dapat bertanya dengan guru dan guru membimbing siswa agar dapat menemukan konsep. Pertanyaan-pertanyaan yang diberikan dapat melatihkan kemampuan pemecahan masalah siswa dalam melakukan rencana, siswa dapat menyelesaikan masalah dengan strategi yang digunakan dengan hasil yang benar.

$\begin{array}{ll}\text { Pada pembelajaran } & \text { LKS 1, } \\ \text { siswa diharapkan mampu } & \text { man }\end{array}$ mendefinisikan garam menghidrolisis, sebelum itu siswa mengelompokkan terlebih dahulu larutan garam yang bersifat netral, asam, dan basa berdasarkan data hasil pengamatan pada percobaan yang telah dilakukan, kemudian siswa menuliskan komponen asam dan basa penyusun dari larutan garam bersifat netral, dan basa. Siswa dapat menjawab komponen asam dan basa, karena ini merupakan pelajaran yang telah diberikan oleh guru di materi konsep asam basa, sehingga semua kelompok menjawab dengan benar. Namun ketika diberi reaksi garam $\mathrm{NaCl}$ dalam air siswa kesulitan untuk menjawab apa yang dimaksud dengan garam yang menghidroisis, sehingga hanya 1 kelompok yang menjawab hampir benar. Berikut ini jawaban dari kelompok tersebut "Garam menghidrolisis adalah garam yang dapat bereaksi dengan air. Jadi garam tersebut dapat memecah molekul air". 
$\begin{array}{lr}\text { Pada pembelajaran } & \text { LKS } 2 \\ \text { diharapkan siswa } & \text { dapat } \\ \text { menyimpulkan definisi garam yang } \\ \text { tidak menghidrolisis, garam }\end{array}$ menghidrolisis sebagian dan garam menghidrolisis total. Pertama-tama siswa menuliskan reaksi ionisasi larutan $\mathrm{NaCl}$ kemudian membandingkan $\mathrm{pH} \mathrm{NaCl}$ tersebut dengan $\mathrm{pH}$ air lalu menuliskan reaksi antara ion $\mathrm{Na}^{+}$dan $\mathrm{Cl}^{-}$dengan $\mathrm{H}_{2} \mathrm{O}$. Jawaban siswa yang mendefinisikan garam tidak menghidrolisis yaitu "garam yang tidak terionisasi, dan ion garam tidak bereaksi dengan air, maka tidak terjadi hidrolisis sehingga tidak memecah molekul air. Pada definisi garam menghidrolisis sebagian pertanyaan-pertanyaan yang diberikan sama dengan yang mengkonstruk garam yang tidak menghidrolisis namun larutan garam yang digunakan yaitu $\mathrm{CH}_{3} \mathrm{COONa}$ dan $\mathrm{NH}_{4} \mathrm{Cl}$. Jawaban siswa yaitu "karena hanya sebagian ion yang mengalami reaksi hidrolisis". Jawaban siswa kurang tepat, jawaban yang benar yaitu "garam yang hanya salah satu dari kation atau anionnya saja yang dapat bereaksi dengan air"

Pada definisi garam menghidrolisis total siswa menuliskan reaksi ionisasi larutan $\mathrm{NH}_{4} \mathrm{CN}$ kemudian membandingkan $\mathrm{pH}$ larutan garam dengan $\mathrm{pH}$ air lalu siswa menuliskan persamaan reaksi garam $\mathrm{NH}_{4} \mathrm{CN}$ dalam air dan yang terakhir siswa menuliskan apa yang dimaksud garam menghidrolisis total. Jawaban siswa yaitu "Garam yang berasal dari asam lemah dengan asam lemah atau basa lemah dan asam lemah dan menghasilkan $\left(\mathrm{OH}^{-}\right)$ $\left(\mathrm{H}^{+}\right)$. Jawaban siswa tentang garam menghidrolisis total kurang tepat. Jawaban yang tepat yaitu "garam yang berasal dari asam lemah dan basa lemah, sehingga kation dan anionnya dapat bereaksi dengan air". Pada LKS 3 terdapat 3 penggalan dimana masing-masing penggalan untuk dapat menemukan rumus $\mathrm{pH}$. Penggalan pertama untuk menemukan rumus umum $\left[\mathrm{H}^{+}\right]$untuk garam yang menghidrolisis sebagian yang bersifat asam. Penggalan kedua menemukan rumus umum $\left[\mathrm{OH}^{-}\right]$ untuk garam yang menghidrolisis sebagian yang bersifat basa, dan yang terakhir untuk menemukan rumus $\left[\mathrm{H}^{+}\right]$dan $\left[\mathrm{OH}^{-}\right]$yang sifatnya ditentukan dari nilai $\mathrm{Ka}$ dan $\mathrm{Kb}$. Pertama-pertama siswa menuliskan konstanta kesetimbangan reaksi ioni $\mathrm{NH}_{4}^{+}$dengan $\mathrm{H}_{2} \mathrm{O}$ kemudian siswa menganalisis hubungan antara konstanta kesetimbangan basa lemah $(\mathrm{Kb})$, konstanta kesetimbangan air $(\mathrm{Kw})$ dengan konstanta hidrolisis (Kh) senyawa garam $\mathrm{NH}_{4} \mathrm{Cl}$ berdasarkan hubungan persamaan reaksinya. Setelah itu siswa menuliskan konstanta hidrolisis (Kh) dari garam $\mathrm{NH}_{4} \mathrm{Cl}$ kemudian menganalisis hubungan antara $\left[\mathrm{H}^{+}\right]$dengan rumus konstanta hidrolisis (Kh) pada senyawa $\mathrm{NH}_{4} \mathrm{Cl}$. Untuk rumus yang bersifat basa $\left[\mathrm{OH}^{-}\right]$, pertanyaan yang mengkonstruk sama dengan rumus bersifat asam namun garam yang digunakan yaitu garam $\mathrm{CH}_{3} \mathrm{COONa}$ (basa) dan konstanta kesetimbangan asam lemah (Ka). siswa sudah menjawabnya dengan tepat. Kemudian siswa melanjutkan menjawab pertanyaan-pertanyaan untuk mendapatkan rumus umum $\left[\mathrm{H}^{+}\right]$dan $\left[\mathrm{OH}^{-}\right]$garam menghidrolisis total.

Pertama - tama siswa menuliskan konstanta kesetimbangan dari reaksi hidrolisis total ion $\mathrm{CH}_{3} \mathrm{COO}^{-}$, $\mathrm{NH}^{+}$dengan $\mathrm{H}_{2} \mathrm{O}$, kemudian menganalisis hubungan antara konstanta hidrolisis dengan 
$1 / \mathrm{Ka}, 1 / \mathrm{Kb}$ dan $1 / \mathrm{Kw}$ dan konstanta kesetimbangan asam lemah $\left(\mathrm{CH}_{3} \mathrm{COOH}\right)$ dan basa lemah $\left(\mathrm{NH}_{4} \mathrm{OH}\right)$ setelah itu siswa menuliskan rumus $\left[\mathrm{H}^{+}\right]$dan $\left[\mathrm{OH}^{-}\right]$ senyawa garam $\mathrm{CH}_{3} \mathrm{COONH}_{4}$. Jawaban siswa terkait rumus $\left[\mathrm{H}^{+}\right]$ dan $\left[\mathrm{OH}^{-}\right]$untuk garam menghidrolisis total atau yang bergantung pada nilai $\mathrm{Ka} / \mathrm{Kb}$ sudah tepat. Pada pembelajaran LKS 1 kerjasama siswa tiap kelompok dapat dikatakan kurang, hal ini dapat dilihat saat menjawab pertanyaanpertanyaan di LKS, murid yang berdiskusi tiap kelompok hanya 2 atau 3 orang saja dari 6 orang. Namun pada pembelajaran LKS 2 dan 3 semua siswa antusias dalam menjawab pertanyaan-pertanyaan dan lebih komunikatif, serta bertanya dengan pertanyaan yang tentunya sesuai dengan pertanyaan yang diharapkan guru.

\section{Tahap Aplikasi}

Pada tahap ini siswa mengaplikasikan konsep yang telah ditemukan untuk menyelesaikan soal latihan yang diberikan oleh guru. Hal ini dapat melatihkan indikator melakukan rencana dan memeriksa kembali pemecahan ditunjukkan dengan siswa mampu menyelesaikan masalah dengan strategi yang iya gunakan dengan hasil benar. Pada LKS , dari 6 kelompok, ada 3 kelompok yang menjawab dengan cukup baik.

Jawaban siswa pada tahap aplikasi nomor 1 tentang pengelompokkan 6 garam yang ada dalam laboratorium kimia berdasarkan sifatnya untuk larutan $\mathrm{Na}_{2} \mathrm{SO}_{4} \quad$ (AK). AK yang dimaksudkan siswa yaitu asam kuat dan (BL) yaitu basa lemah.
Kemudian ada kekeliruan dalam menentukan asam pembentuk di larutan $\quad \mathrm{NH}_{4} \mathrm{NO}_{3}$ karena $\mathrm{HNO}_{3}$ seharusnya termasuk ke dalam asam kuat sehingga sifatnya garam tersebut pun bersifat asam. Selain itu, jawaban siswa sudah tepat.

Pada pembelajaran LKS 2 di tahap aplikasi tentang analisis garam yang menghidrolisis terdapat 2 butir soal dan hanya ada 1 kelompok yang dapat menjawab dengan benar dan tepat. Kelompok lainnya sudah menjawab namun hanya 1 nomor saja yang sudah tepat.

Pada pembelajaran LKS 3 aplikasi tentang perhitungan $\mathrm{pH}$ yang dikerjakan sudah lebih meningkat dari LKS 2 karena 2 kelompok dapat menjawab dengan dan benar dan 4 kelompok lain menjawab dengan cukup baik. Pada pembelajaran LKS 1 sampai LKS 3 dapat terlihat bahwa kelompok yang dapat menjawab dengan benar sudah meningkat dan tidak ada kelompok yang menjawab salah/ tidak menjawab. Hal ini tentu saja karena siswa sudah memahami konsep yang ditemukan pada tahap menemukan konsep.

\section{Tahap Penutup}

Pada tahap ini guru mengajak siswa bersama-sama mengevaluasi materi yang telah didapat yaitu dengan cara 1 kelompok diminta memberikan kesimpulan materi pelajaran dan kelompok yang lain menanggapi. Pada tahap ini kemampuan masalah siswa dapat dilatihkan pada kemampuan memeriksa kembali kebenaran hasil atau jawaban. 
Pada pembelajaran LKS 1, siswa yang memiliki keaktifan yang tinggi yang menjadi perwakilan kelompok dalam mengomunikasikan hasil diskusinya namun pada pembelajaran LKS 2 dan 3 pada tiap kelompok mulai terjadi perbedaan yaitu yang menjadi juru bicara untuk mengomunikasikan hasil diskusinya semakin banyak yang berminat.

\section{SIMPULAN}

Berdasarkan hasil analisis dan pembahasan dalam penelitian dapat disimpulkan bahwa: (1). Ratarata $n$-gain kemampuan pemecahan masalah siswa dikelas eksperimen yang diterapkan model pembelajaran POGIL lebih tinggi daripada rata-rata $n$-gain pemecahan masalah siswa yang diterapkan pembelajaran konvensional; (2). Terdapat perbedaan $n$-gain yang signifikan antara kelas eksperimen dan kelas kontrol; (3). Model pembelajaran POGIL efektif untuk meningkatkan kemampuan pemecahan masalah pada materi garam menghidrolisis.

\section{DAFTAR RUJUKAN}

Bagus P. 2015. Menilik Kesiapan Dunia Ketenaga - kerjaan Indonesia Menghadapi MEA. Rechtsvinding online Journal, 13(2): 293-301.

Behrman, Kliegman, dan Arvin. 2000. Nelson Ilmu Kesehatan Anak Edisi. EGC. Jakarta.

Brickman, P. 2009. Effect of Inquiry based Learning on Students' Science Literacy Skills and Confidence. International Journal Scholarship of Teaching and Learning, 3(2): 1-22.
Cottrell, S. 2005. Critical Thinking Skills Developing Effective Analysis and Argument. Palgrave Macmilla. New York.

Fathoni. 2015. Masyarakat Ekonomi Asean (MEA) 2015 dan Tantangan Negara Kesejahteraan. Jurnal Penelitian Hukum, 24 (2): 124-133.

Hake, R. R. 1998. InteractiveEngagement Versus Traditional Methods: A Six Thousand-Student Survey of Mechanics Test Data For Introductory Physics Courses. American Journal of Physics, 66(1): 64-74.

Hale, D dan Mullen. 2009. Designing Process Oriented Guided-Inquiry Activities: A New Innovation for Marketing Classes. Marketing Education Review, 19(1): 74-80.

Hanson. 2006. Beyond constructivism: Models and modeling perspective on physics problem solving, learning, and teaching. LEA. London.

Nugraheni, F. 2014. Keefektifan model process oriented guided inquiry learning terhadap kemampuan pemecahan masalah. Unnes journal of mathematics education, 3 (1): 2-3.

Sanggara, Doyan dan Verawati. 2017. Pembelajaran POGIL dalam Virtual laboratory dapat meningkatkan kemampuan pemecahan masalah. Journal penelitian pendidikan IPA, 5(1):62.

Septianawati. 2017. Peningkatkan Kemampuan Pemecahan Masalah Matematis Dan Habits Of Mind Siswa Melalui 
Model Pembelajaran Process Oriented Guided Inquiry

Learning). S2 (Thesis).

Universitas Pendidikan

Indonesia.
Simonson, S. R. dan Susan E. S. 2013. Implementing POGIL in Undergraduate Biomechanics: Lessons Learned by A Novice. Journal of STEM Education, 1(14): 56-63. 